86

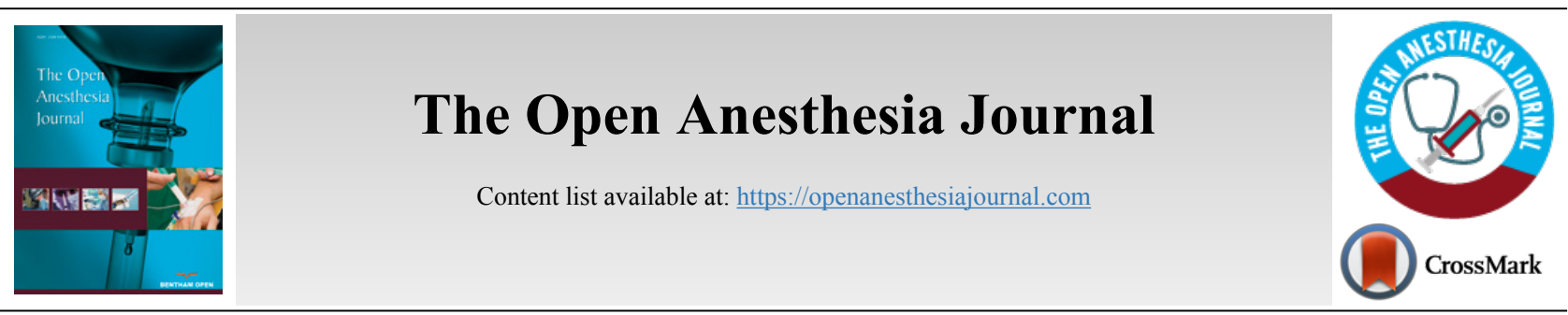

CLINICAL TRIAL STUDY

\title{
Impact of Sub-Anesthetic Dose of Ketamine on Post Spinal Hypotension in Cesarean Delivery
}

Dina Salah ${ }^{1, *}$ and Amin Mohammed Alansary ${ }^{1}$

${ }^{I}$ Department of Anesthesiology, Intensive Care, and Pain Management, Faculty of Medicine, Ain Shams University, Cairo, Egypt

\begin{abstract}
:
Background:

Spinal anesthesia is the commonest technique used in Cesarean Section (CS) and most frequently associated with maternal hypotension, for which a lot of techniques have been described to prevent but an effective method is yet to be found.

Objectives;

The aim was to study the effect of using a sub-anesthetic dose of ketamine to prevent post-spinal hypotension in CS delivery.

Methods:

This double-blinded randomized controlled study was conducted on 80 participating parturients who were ASA I, $\Pi$ term pregnant. All the parturients received spinal anesthesia. The parturients were then randomly divided into two equal groups ( $\mathrm{n}=40 \mathrm{in}$ each); ketamine group received a sub-anesthetic dose of ketamine of $0.5 \mathrm{mg} / \mathrm{kg}$ IV bolus in $3 \mathrm{ml}$ saline and control group received the same volume of normal saline IV bolus. Heart Rate (HR) and Mean Arterial blood Pressure (MAP) were recorded at baseline (5 minutes prior to the intrathecal injection), at 5, 10, 15 and 20 minutes after the injection and then every 15 minutes till the end of the operation. Incidences of hypotension and severe hypotension were recorded. The total dose of ephedrine was recorded. Ramsay sedation score was recorded at baseline then 5, 10, 15, 30, 45 minutes after injection and then at the end of the operation.

Results:

Compared to the control group, sedation score was significantly higher among ketamine group at 5, 10 and 15 minutes. MAP and HR were significantly higher among ketamine group at 5, 10, 15, and 20 minutes. Total ephedrine dose was significantly lower among the ketamine group. Mild hypotension and severe hypotension were significantly less frequent among the ketamine group, as all the patients in the control group had an attack of mild hypotension and $55 \%$ of this group had an attack of severe hypotension. No significant difference between both the groups regarding diplopia, nystagmus, hallucination, nausea and vomiting.

\section{Conclusion:}

It is concluded that ketamine in a sub-anesthetic dose is an effective agent that can be used in preventing post-spinal hypotension in parturients undergoing CS delivery.
\end{abstract}

Keywords: Sub-anesthetic dose, Post spinal hypotension, Cesarean section delivery, Spinal anesthesia, Ketamine, Neonatal response, Hypotension. Received: May 11,2019 Revised: July 10, 2019 Accepted: July 22, 2019

\section{INTRODUCTION}

Cesarean section is one of the most commonly performed surgical procedures; approximately $80-90 \%$ of elective cesa-

\footnotetext{
* Address correspondence to this author at the Department of Anesthesiology, Intensive Care, and Pain Management, Faculty of Medicine, Ain Shams University, Cairo, Egypt; Tel: +20 1223606450;

E-mail: dinabadre2013@gmail.com
}

rean sections are conducted using spinal anesthesia [1]. Spinal anesthesia is the preferred technique for Cesarean Section (CS) due to its simplicity, reliability, low rates of airway complications, facilitation of postoperative analgesia, less neonatal exposure to potentially depressant drugs, to awake mother at the time of the birth of the child that establishes maternal-infant bonding and successful breastfeeding, and due to its low cost as compared to the general anesthesia [2]. Maternal hypo- 
tension is a frequent side effect of spinal anesthesia for cesarean delivery and it causes dangerous maternal and fetal effects $[3,4]$.

Maternal hypotension decreases uteroplacental circulation and it results in nausea, vomiting, bradycardia and different systems dysfunction particularly in the presence of other diseases as renal, hepatic, cardiac and neurological $[5,6]$. Anesthesiologists should not allow hypotension to continue, this often requires the use of vasopressors to maintain blood pressure as ephedrine, phenylephrine and norepinephrine [7,8].

Ketamine, is a non- competitive antagonist at the NMethyl-D-Aspartic Acid (NMDA) receptor [9], stimulating the cardiovascular system with high blood pressure, heart rate, and cardiac output. These changes are not related to the dose of ketamine [10]. The mechanism by which ketamine stimulates the cardiovascular system seems to be the central reason rather than peripheral. Ketamine attenuates the baroreceptor effect by blocking the NMDA receptors in the nucleus tractus solitarius. This effect results in a centrally mediated sympathetic response [11].

This study was performed to evaluate the effect of subanesthetic dose of ketamine to prevent maternal hypotension after spinal anesthesia in cesarean section.

\section{PATIENTS AND METHODS}

This double-blinded randomized controlled study was conducted between February 2018 till May of the same year in Ain Shams University hospital after approval of the research ethical committee (clinical trials ID is 03624166, Ethical number is FAMUS R 38/2018) and obtaining written informed consent from all participants. It included 80 patients admitted for elective cesarean section, all were term pregnant and of ASA physical status grade I or П. Parturients who had preeclampsia, chronic hypertension, cardiovascular troubles, any contraindication to regional anesthesia such as local infection or bleeding disorders or any hypersensitivity to ketamine were excluded from the study (Fig. 1).

All the parturients were randomly allocated into two groups using computer-generated random numbers list and opaque sealed envelopes. Study drugs were prepared by an anesthesiologist independent of the study.
An Intravenous (IV) infusion of lactated Ringer's solution at $5-7 \mathrm{ml} / \mathrm{kg}$ prior to the subarachnoid block was started in the operating room in all participants. Standard anesthesia monitoring was applied. Spinal anesthesia was performed with patients in the sitting position in the midline approach at the L2-3 or L3-4 level, with a 25G Quincke needle, local anesthesia of $1.5 \mathrm{ml}$ of $2 \%$ lidocaine and then intrathecal bupivacaine $10 \mathrm{mg}$ was injected. All the patients were then placed supine with the table tilted 15 left lateral tilt. The parturients were then divided into two groups; ketamine group $(\mathrm{n}=40)$ received a sub-anesthetic dose of ketamine of 0.5 $\mathrm{mg} / \mathrm{kg}$ IV bolus in $3 \mathrm{ml}$ of normal saline and the control group $(n=40)$ received the same volume of normal saline IV bolus. All the parturients received $2 \mathrm{mg}$ midazolam IV directly after delivery of the fetus.

Heart Rate (HR) and Mean Arterial Blood Pressure (MAP) were recorded at baseline 5 minutes prior to the intrathecal injection and 5 minutes, 10 minutes, 15 minutes, and 20 minutes after the injection and then every 15 minutes till the end of the operation. Incidence of hypotension was recorded which was defined as MAP less than $20 \%$ below the baseline or was $\leq 65 \mathrm{mmHg}$. Incidence of severe hypotension $\leq 50$ $\mathrm{mmHg}$ was recorded. On the occurrence of hypotension, ephedrine $5 \mathrm{mg}$ was then administered intravenously, repeated if needed and total dose of ephedrine was recorded. Also, if HR was $<50$ beats/minute, atropine sulfate $0.5 \mathrm{mg}$ was administered intravenously.

Ramsay sedation scale was used to evaluate the sedation effect at baseline in both groups then, at 5, 10, 15, 30, 45 minutes after intrathecal injection and then at the end of the operation (Table 1).

Table 1. Ramsay sedation score [12].

\begin{tabular}{|c|c|}
\hline Ramsay Score & Level of Sedation \\
\hline 1 & Anxious, agitated, restless \\
\hline 2 & Oriented, tranquil \\
\hline 3 & Responds to commands \\
\hline 4 & Brisk response to light glabellar tap \\
\hline 5 & Sluggish response to light glabellar tap \\
\hline 6 (deep sedation) & No response \\
\hline
\end{tabular}

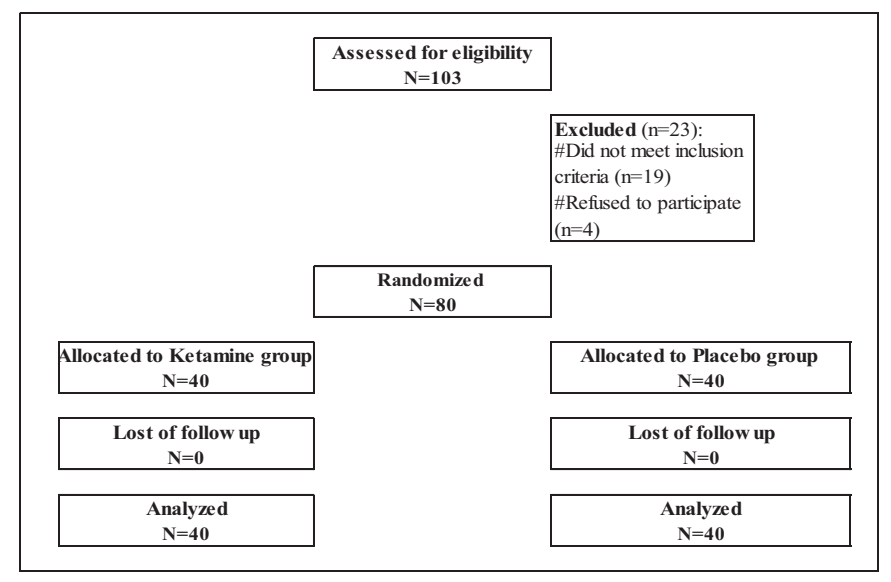

Fig (1). Flow chart of the studied cases. 
Incidence of hypotension and total dose of ephedrine used in both the groups were considered the primary outcomes. APGAR scores of neonates were measured at first and fifth minutes after childbirth together with umbilical artery ABG.

\subsection{Ethical Approval and Registered Clinical Trials}

Clinical trials ID is 03624166 , Ethical number is FAMUS R 38/2018.

\subsection{Sample Size}

It was assumed that $20 \%$ difference in the incidence of hypotension among the two groups, with a two-sided comparison, would be clinically significant. Based on this assumption, a sample size for each group was calculated to be 35 at an alpha error of 0.05 and a beta error of 0.1 (power of $90 \%$ ). Forty patients were enrolled in each group to accommodate for possible dropouts.

\subsection{Statistical Methods}

The collected data were coded, tabulated, and statistically analyzed using IBM SPSS statistics (Statistical Package for Social Sciences) software version 18.0, IBM Corp., Chicago, USA, 2009.
Descriptive statistics were calculated for quantitative data as mean $\pm \mathrm{SD}$ (standard deviation), while qualitative data were calculated in numbers and percentages.

Inferential analyses were performed for quantitative variables using independent t-test in cases of two independent groups with normally distributed data and Friedman's test for more than two dependent groups with non normally distributed data. Normality testing was done using the Shapiro-Wilk test. In qualitative data, inferential analyses for independent variables were performed using Chi-square test for differences between proportions and Fisher's Exact test for variables with small (less than 5) expected numbers. The level of significance was taken at $P$-value $<0.5$.

\section{RESULTS}

No significant difference between the studied groups regarding baseline characteristics (Table 2).

Sedation score was significantly higher among the ketamine group at 5, 10 and 15 minutes compared to the control group (Table 3).

No significant difference between the studied groups regarding umbilical artery ABG findings and APGAR scores at 1 and 5 minutes (Table 4).

Table 2. Baseline characteristics and delivery characteristics.

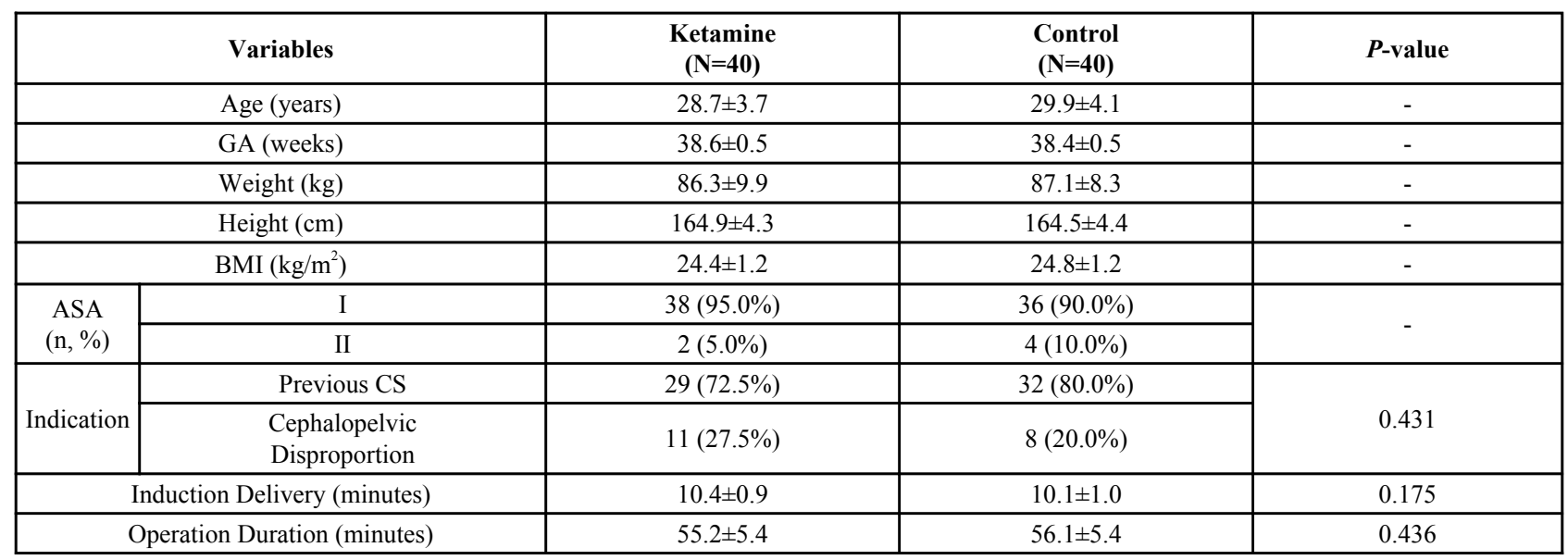

$\mathrm{GA}=$ Gestational Age.

Table 3. Sedation score among the studied cases.

\begin{tabular}{|c|c|c|c|}
\hline Time & $\begin{array}{c}\text { Ketamine } \\
(\mathbf{N}=\mathbf{4 0})\end{array}$ & $\begin{array}{c}\text { Control } \\
(\mathbf{N}=\mathbf{4 0})\end{array}$ & $\boldsymbol{P}$-value \\
\hline Minute-5 & $4.0(3.0-4.0)$ & $2.0(1.0-2.0)$ & $<\mathbf{0 . 0 0 1}$ * \\
\hline Minute-10 & $4.0(3.0-4.0)$ & $2.0(1.0-2.0)$ & $<\mathbf{0 . 0 0 1}$ * \\
\hline Minute-15 & $3.0(3.0-4.0)$ & $2.0(1.0-2.0)$ & $<\mathbf{0 . 0 0 1}$ * \\
\hline Minute-30 & $2.0(1.0-2.0)$ & $2.0(1.0-2.0)$ & 0.172 \\
\hline Minute-45 & $2.0(1.0-2.0)$ & $2.0(1.0-2.0)$ & 0.110 \\
\hline End & $2.0(1.0-2.0)$ & $2.0(1.0-2.0)$ & 0.143 \\
\hline
\end{tabular}

Data presents as Median (IQR). ${ }^{\wedge}$ Mann Whitney test, *Significant 
Table 4. Neonatal condition among the studied cases.

\begin{tabular}{|c|c|c|c|}
\hline Variables & $\begin{array}{c}\text { Ketamine } \\
(\mathbf{N}=\mathbf{4 0})\end{array}$ & $\begin{array}{c}\text { Control } \\
(\mathbf{N}=\mathbf{4 0})\end{array}$ & $\boldsymbol{P}$-value \\
\hline $\mathrm{pH}$ & $7.3 \pm 0.0$ & $7.3 \pm 0.0$ & 0.391 \\
\hline Base excess & $0.9 \pm 0.0$ & $0.9 \pm 0.0$ & 0.160 \\
\hline Bicarbonates & $22.6 \pm 2.1$ & $22.9 \pm 2.0$ & 0.512 \\
\hline APGAR-1 min & $7.9 \pm 0.4$ & $7.7 \pm 0.5$ & 0.207 \\
\hline APGAR-5 min & $9.6 \pm 0.6$ & $9.7 \pm 0.5$ & 0.680 \\
\hline
\end{tabular}

Table 5. MAP (mmHg) among the studied cases.

\begin{tabular}{|c|c|c|c|c|c|}
\hline \multirow{2}{*}{ Time } & \multirow{2}{*}{$\begin{array}{c}\text { Ketamine } \\
(\mathrm{N}=40)\end{array}$} & \multirow{2}{*}{$\begin{array}{l}\text { Control } \\
(\mathrm{N}=40)\end{array}$} & \multirow{2}{*}{$P$-value } & \multicolumn{2}{|c|}{ Difference (Ket- Control) } \\
\hline & & & & Mean \pm SE & $95 \%$ CI \\
\hline Base & $95.0 \pm 3.4$ & $94.5 \pm 3.2$ & 0.477 & $0.5 \pm 0.7$ & $-0.9-2.0$ \\
\hline Minute-5 & $94.3 \pm 6.0$ & $51.7 \pm 11.3$ & $<0.001^{*}$ & $42.6 \pm 2.0$ & $38.6-46.6$ \\
\hline Minute-10 & $94.3 \pm 5.9$ & $76.0 \pm 12.1$ & $<0.001^{*}$ & $18.3 \pm 2.1$ & $14.0-22.5$ \\
\hline Minute-15 & $94.2 \pm 5.8$ & $85.8 \pm 12.5$ & $<0.001^{*}$ & $8.5 \pm 2.2$ & $4.1-12.8$ \\
\hline Minute-20 & $97.5 \pm 5.9$ & $88.2 \pm 14.8$ & $0.001 *$ & $9.3 \pm 2.5$ & $4.3-14.3$ \\
\hline Minute-35 & $98.3 \pm 5.9$ & $94.9 \pm 14.7$ & 0.181 & $3.4 \pm 2.5$ & $-1.6-8.4$ \\
\hline Minute-50 & $95.2 \pm 5.9$ & $90.9 \pm 14.7$ & 0.088 & $4.4 \pm 2.5$ & $-0.6-9.3$ \\
\hline Minute-65 & $95.1 \pm 5.9$ & $93.6 \pm 14.8$ & 0.555 & $1.5 \pm 2.5$ & $-3.5-6.5$ \\
\hline End & $95.2 \pm 5.8$ & $93.7 \pm 14.6$ & 0.556 & $1.5 \pm 2.5$ & $-3.5-6.4$ \\
\hline Ephedrine Dose (mg) & $0.9 \pm 2.2$ & $26.3 \pm 5.3$ & $<0.001 *$ & $-25.4 \pm 0.9$ & $-27.1-23.6$ \\
\hline
\end{tabular}

*Significant, CI: Confidence Interval.

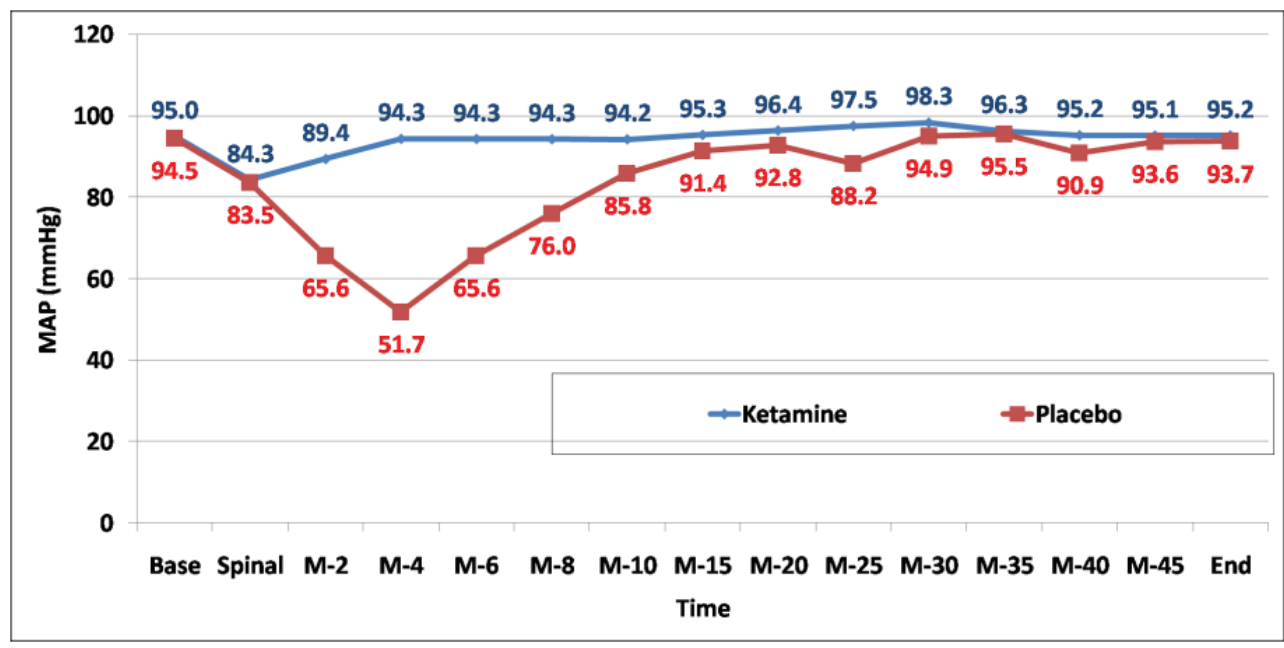

Fig (2). MBP (mmHg) characteristics.

MAP was significantly higher among the ketamine group compared to control at 5, 10,15, and 20 minutes. Total ephedrine dose was significantly lower among the ketamine group compared to control (Fig. 2) and (Table 5).

Heart rate was significantly higher among the ketamine group at 5, 10, 15, and 20 minutes (Fig. 3) and (Table 6).

Table 6. Heart rate (beat/minute) among the studied cases.

\begin{tabular}{|c|c|c|c|c|c|}
\hline \multirow{2}{*}{ Time } & $\begin{array}{c}\text { Ketamine } \\
(\mathbf{N}=\mathbf{4 0})\end{array}$ & $\begin{array}{c}\text { Control } \\
\mathbf{( N = 4 0 )}\end{array}$ & \multirow{2}{*}{ P-value } & \multicolumn{2}{|c|}{ Difference (Ket- Control) } \\
\cline { 3 - 6 } & $90.5 \pm 5.0$ & $89.7 \pm 5.2$ & 0.498 & $0.8 \pm 1.1$ \\
\hline Base & $91.9 \pm 5.8$ & $71.0 \pm 2.1$ & $<0.001 *$ & $20.9 \pm 1.0$ & $-1.5-3.0$ \\
\hline Minute-5 & $100.7 \pm 5.8$ & $51.1 \pm 9.7$ & $<0.001 *$ & $49.6 \pm 1.8$ \\
\hline
\end{tabular}


(Table 6) contd.....

\begin{tabular}{|c|c|c|c|c|c|}
\hline \multirow{2}{*}{ Time } & \multirow{2}{*}{$\begin{array}{c}\text { Ketamine } \\
(\mathrm{N}=40)\end{array}$} & \multirow{2}{*}{$\begin{array}{c}\text { Control } \\
(\mathrm{N}=\mathbf{4 0})\end{array}$} & \multirow{2}{*}{$P$-value } & \multicolumn{2}{|c|}{ Difference (Ket- Control) } \\
\hline & & & & $\operatorname{Mean} \pm \mathrm{SE}$ & $95 \% \mathrm{CI}$ \\
\hline Minute-15 & $112.3 \pm 5.1$ & $79.2 \pm 10.0$ & $<0.001^{*}$ & $33.1 \pm 1.8$ & $29.6-36.7$ \\
\hline Minute-20 & $118.3 \pm 5.1$ & $112.7 \pm 10.1$ & $0.002 *$ & $5.6 \pm 1.8$ & $2.0-9.2$ \\
\hline Minute-35 & $118.9 \pm 4.2$ & $115.5 \pm 10.1$ & 0.052 & $3.4 \pm 1.7$ & $0.0-6.9$ \\
\hline Minute-50 & $119.4 \pm 3.4$ & $116.6 \pm 10.2$ & 0.106 & $2.8 \pm 1.7$ & $-0.6-6.2$ \\
\hline Minute- 65 & $120.3 \pm 2.5$ & $117.6 \pm 10.1$ & 0.101 & $2.7 \pm 1.6$ & $-0.5-6.0$ \\
\hline End & $91.3 \pm 2.3$ & $89.6 \pm 10.0$ & 0.313 & $1.7 \pm 1.6$ & $-1.6-4.9$ \\
\hline
\end{tabular}

*Significant, CI: Confidence Interval

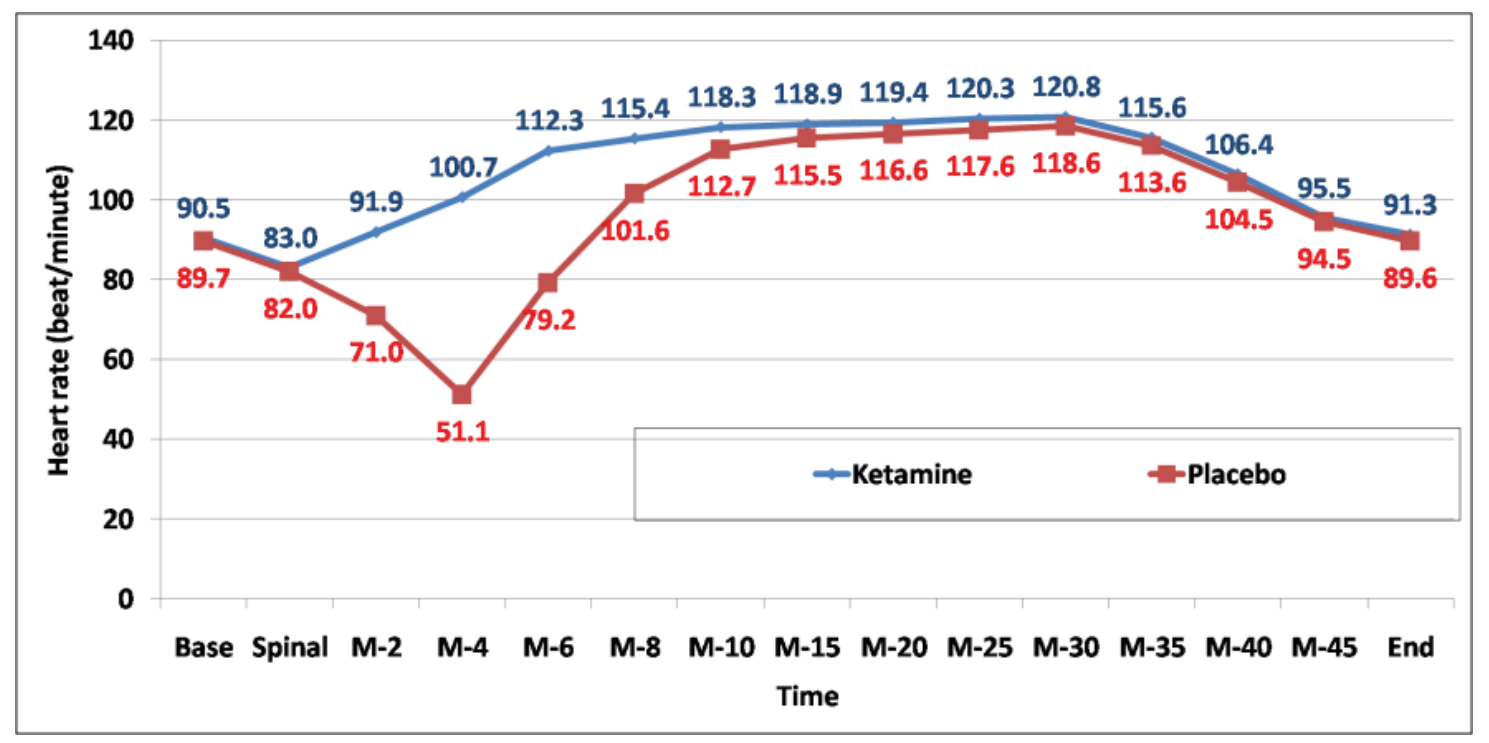

Fig (3). Heart rate among the studied cases.

Table 7. Side effects among the studied groups.

\begin{tabular}{|c|c|c|c|c|}
\hline Time & $\begin{array}{c}\text { Ketamine } \\
(\mathbf{N}=\mathbf{4 0})\end{array}$ & $\begin{array}{c}\text { Placebo } \\
(\mathbf{N}=\mathbf{4 0})\end{array}$ & P-value & $\begin{array}{c}\text { RR } \\
\mathbf{( 9 5 \%} \mathbf{C I})\end{array}$ \\
\hline Mild Hypotension & $6(15.0 \%)$ & $40(100.0 \%)$ & $\#<\mathbf{0 . 0 0 1 *}$ & -- \\
\hline Severe Hypotension & $0(0.0 \%)$ & $22(55.0 \%)$ & $\#<\mathbf{0 . 0 0 1 *}$ & -- \\
\hline Diplopia & $3(7.5 \%)$ & $0(0.0 \%)$ & $\& 0.241$ & -- \\
\hline Nystagmous & $2(5.0 \%)$ & $0(0.0 \%)$ & $\& 0.494$ & -- \\
\hline Hallucination & $4(10.0 \%)$ & $0(0.0 \%)$ & $\& 0.116$ & -- \\
\hline Nausea \& Vomiting & $2(5.0 \%)$ & $6(15.0 \%)$ & $\& 0.263$ & $0.33(0.07-1.55)$ \\
\hline
\end{tabular}

\#Chi square test \& Fisher's exact test, *Significant, RR: Relative Rate, CI: Confidence Interval.

Mild hypotension and severe hypotension were significantly less frequent among the ketamine group. Diplopia, nystagmus and hallucination were non-significant between both the groups. Nausea and vomiting were non-significant between both the groups (Table 7).

\section{DISCUSSION}

This study showed that sedation score was significantly higher among the ketamine group with greater hemodynamic stability regarding MAP and HR with less frequent attacks of mild hypotension and no attacks of severe hypotension, with lower total ephedrine dose compared to control group. No difference between both the groups was observed regarding the incidence of other complications or regarding umbilical artery ABG findings and APGAR scores.
Regional anesthesia is performed now in $95 \%$ of scheduled CS delivery, as it avoids the risks of pulmonary aspiration, esophageal intubation that may occur with general anesthesia, and it allows the mother to be awake and interact immediately with her baby [13]. The commonest complication due to spinal anesthesia is hypotension with a reported incidence more than $80 \%$, which may have detrimental effects on decreasing uterine blood flow, affecting the fetal well-being and ultimately neonatal outcome measured by umbilical artery $\mathrm{pH}$ and Apgar scores [14].

Hypotension that occurs in spinal anesthesia is due to sympathetic nervous system blockade in addition to inferior vena cava and aorta compression in a parturient. It is usually easily treated with left lateral tilt, intravenous fluid, and 
sympathomimetic drugs such as ephedrine. A lot of techniques have been described in the hope of eliminating hypotension in parturients during spinal anesthesia, but an effective method is yet to be described. These techniques include intravenous fluid prehydration [15] and cohydration [16], sympathomimetic drugs [17], physical methods such as leg bindings and compression stockings [18].

Ketamine is a unique drug that has stood the test of time since being introduced in 1970 with a wide variety of uses including sedation, analgesia, bronchodilation, and sympathetic nervous system stimulation [19]. Since ketamine increases the release and inhibits the reuptake of catecholamines in circulation, thus helps preserve vascular resistance and arterial Blood Pressure (BP), all these have made it an optimal anesthetic agent in hypotensive patients. In a study, ketamine in a dose of $0.7 \mathrm{mg} / \mathrm{kg}$ before spinal anesthesia, then 0.35 $\mathrm{mg} / \mathrm{kg} 15$ and $30 \mathrm{~min}$ after the first dose for osteosynthesis of hip fractures kept the patients hemodynamically stable than fentanyl given in a dose of $1.5 \mu \mathrm{g} / \mathrm{kg}$ before anesthesia [20]. These criteria can help in using ketamine to prevent hypotension that commonly occurs after spinal anesthesia during CS in parturients, as proven by our study, an alternative method that proved to be effective.

Previous animal and human studies have suggested that the fetus adapts to decreased Uterine Blood Flow (UBF) temporarily by redistributing cardiac output to the cerebral cortex, this compensatory reflex, however, is inhibited by both intravenous and inhalational anesthetics while ketamine does not suppress it due to its ability to increase maternal BP and UBF, thus improving uterine perfusion [21]. Ketamine at doses less than $2 \mathrm{mg} / \mathrm{kg}$ i.v. does not suppress the neonates assessed by Apgar scores making ketamine an attractive alternative in obstetric anesthesia in cases of severe fetal distress [22]. In the current study, umbilical artery ABG and Apgar scores were not affected in either groups.

In this study, although the sedation score was higher among the ketamine group in the first 15 minutes compared to the study group, the parturients were able to maintain airway reflexes with no desaturation at any time. Several studies confirm that ketamine preserves spontaneous respirations and protective airway reflexes $[23,24]$.

Hallucinations that occurred in 4 parturients after ketamine injection was in fact not true hallucinations but some sensory distortions that did not in any way affect the patients postoperatively (no nightmares, vivid dreams and with intact memory). This is in accordance with the study conducted by Powers et al. [25] to describe the ketamine-induced hallucinations and stated that a subanesthetic dose of ketamine does not produce frank hallucinations.

Although no catastrophic events occurred, this study was conducted on a small group of parturients which is considered a limitation to the use of ketamine safely in parturients. Other studies are needed with a much larger group of parturients to consider safety issue.

\section{CONCLUSION}

We concluded that ketamine in subanesthetic dose is an effective agent to be used in preventing post-spinal hypotension in parturients undergoing CS delivery.

\section{LIST OF ABBREVIATIONS}

$\begin{array}{lll}\text { CS } & = & \text { Cesarean Section } \\ \text { HR } & = & \text { Heart Rate } \\ \text { IV } & = & \text { Intravenous } \\ \text { MAP } & = & \text { Mean Arterial Blood Pressure } \\ \text { NMDA } & = & \text { N-Methyl-D-Aspartic Acid } \\ \text { GA } & = & \text { Gestational Age } \\ \text { CI } & = & \text { Confidence Interval }\end{array}$
ETHICS APPROVAL AND CONSENT TO
PARTICIPATE

This double-blinded randomized controlled study was conducted between February 2018 till May of the same year in Ain Shams University hospital after approval of the Research Ethical Committee (clinical trials ID is 03624166, Ethical number is FAMUS R 38/2018).

\section{HUMAN AND ANIMAL RIGHTS}

No animals were used in this research. All human research procedures followed were in accordance with the ethical standards of the committee responsible for human experimentation (institutional and national), and with the Helsinki Declaration of 1975, as revised in 2013.

\section{CONSENT FOR PUBLICATION}

Written informed consent was obtained from all the patients.

\section{STANDARD OF REPORTING}

CONSORT guidelines and methodology were followed.

\section{AVAILABILITY OF DATA AND MATERIAL}

All data and materials are available within the article.

\section{FUNDING}

None.

\section{CONFLICT OF INTEREST}

The authors declare no conflict of interest, financial or otherwise.

\section{ACKNOWLEDGEMENTS}

Declared none.

\section{REFERENCES}

[1] Reynolds F, Seed PT. Anaesthesia for Caesarean section and neonatal acid-base status: A meta-analysis. Anaesthesia 2005; 60(7): 636-53. [http://dx.doi.org/10.1111/j.1365-2044.2005.04223.x] [PMID: 15960 713]

[2] Bryson GL, Macneil R, Jeyaraj LM, Rosaeg OP. Small dose spinal bupivacaine for Cesarean delivery does not reduce hypotension but accelerates motor recovery. Can J Anaesth 2007; 54(7): 531-7. [http://dx.doi.org/10.1007/BF03022316] [PMID: 17602038]

[3] Kashefi P. The benefits of intraoperative small-dose ketamine on postoperative painafter cesarean section. Anesthesiology 2006; 104: 27.

[4] Sen S, Ozmert G, Aydin ON, Baran N, Caliskan E. The persisting analgesic effect of low-dose intravenous ketamine after spinal 
anaesthesia for caesarean section. Eur J Anaesthesiol 2005; 22(7): 518-23.

[http://dx.doi.org/10.1017/S026502150500089X] [PMID: 16045141]

[5] Ralston DH, Shnider SM, DeLorimier AA. Effects of equipotent ephedrine, metaraminol, mephentermine, and methoxamine on uterine blood flow in the pregnant ewe. Anesthesiology 1974; 40(4): 354-70. [http://dx.doi.org/10.1097/00000542-197404000-00009] [PMID: 481 9091]

[6] Lee A, Ngan Kee WD, Gin T. Prophylactic ephedrine prevents hypotension during spinal anesthesia for Cesarean delivery but does not improve neonatal outcome: A quantitative systematic review. Can J Anaesth 2002; 49(6): 588-99.

[http://dx.doi.org/10.1007/BF03017387] [PMID: 12067872]

[7] Rout CC, Rocke DA. Prevention of hypotension following spinal anesthesia for cesarean section. Int Anesthesiol Clin 1994; 32(2): 117-35.

[http://dx.doi.org/10.1097/00004311-199432020-00010] [PMID: 806 3445]

[8] Macarthur A, Riley ET. Obstetric anesthesia controversies: Vasopressor choice for postspinal hypotension during cesarean delivery. Int Anesthesiol Clin 2007; 45(1): 115-32. [http://dx.doi.org/10.1097/AIA.0b013e31802b8d53] [PMID: 17215 703]

[9] Monteggia LM, Zarate C Jr. Antidepressant actions of ketamine: From molecular mechanisms to clinical practice. Curr Opin Neurobiol 2015; 30: $139-43$.

[http://dx.doi.org/10.1016/j.conb.2014.12.004] [PMID: 25562451]

[10] Doenicke A, Angster R, Mayer M, Adams HA, Grillenberger G, Nebauer AE. [The action of S-(+)-ketamine on serum catecholamine and cortisol. A comparison with ketamine racemate]. Anaesthesist 1992; 41(10): 597-603.

[PMID: 1443507]

[11] Ogawa A, Uemura M, Kataoka Y, Ol K, Inokuchi T. Effects of ketamine on cardiovascular responses mediated by N-methyl-Daspartate receptor in the rat nucleus tractus solitarius. Anesthesiology 1993; 78(1): 163-7.

[http://dx.doi.org/10.1097/00000542-199301000-00022] [PMID: 842 4550]

[12] Ramsay MAE, Savege TM, Simpson BRJ, Goodwin R. Controlled sedation with alphaxalone-alphadolone. BMJ 1974; 2(5920): 656-9. [http://dx.doi.org/10.1136/bmj.2.5920.656] [PMID: 4835444]

[13] Ramsay MAE, Savege TM, Simpson BRJ, Goodwin R. Controlled sedation with alphaxalone-alphadolone. BMJ 1974; 2(5920): 656-9. [http://dx.doi.org/10.1136/bmj.2.5920.656] [PMID: 4835444]

[14] Lee A, Warwick Ngan Kee. Prophylactic ephedrine prevents hypotension during spinal anaesthesia for caesarean delivery, but does not improve neonatal outcome-A quantitative systematic review. Can J
Anaesth 2002; 49(6): 588-99

[http://dx.doi.org/10.1007/BF03017387] [PMID: 12067872]

[15] Wollman SB, Marx GF. Acute hydration for prevention of hypotension of spinal anesthesia in parturients. Anesthesiology 1968; 29(2): 374-80.

[http://dx.doi.org/10.1097/00000542-196803000-00024] [PMID: 563 5887]

[16] Dyer RA, Farina Z, Joubert IA, et al. Crystalloid preload versus rapid crystalloid administration after induction of spinal anaesthesia (coload) for elective caesarean section. Anaesth Intensive Care 2004; 32(3): 351-7.

[http://dx.doi.org/10.1177/0310057X0403200308] [PMID: 15264729]

[17] Kang YG, Abouleish E, Caritis S. Prophylactic intravenous ephedrine infusion during spinal anesthesia for cesarean section. Anesth Analg 1982; 61(10): 839-42.

[http://dx.doi.org/10.1213/00000539-198210000-00007] [PMID: 712 5249]

[18] Rout CC, Rocke DA, Gouws E. Leg elevation and wrapping in the prevention of hypotension following spinal anaesthesia for elective caesarean section. Anaesthesia 1993; 48(4): 304-8.

[http://dx.doi.org/10.1111/j.1365-2044.1993.tb06948.x] [PMID: 84 94130]

[19] White PF, Elig MR. Intravenous anaesthetics.Clinical Anaesthesia. 6th ed. China: Lippincott Williams and Wilkins 2013; pp. 478-500.

[20] Hemmingsen C, Nielsen JE. Intravenous ketamine for prevention of severe hypotension during spinal anaesthesia. Acta Anaesthesiol Scand 1991; 35(8): 755-7.

[http://dx.doi.org/10.1111/j.1399-6576.1991.tb03385.x] [PMID: 176 3596]

[21] Tang Y, Liu R, Zhao P. Ketamine: An update for obstetric anesthesia. Transl Perioper Pain Med 2017; 4(4): 1-12.

[22] Maduska AL, Hajghassemali M. Arterial blood gases in mothers and infants during ketamine anesthesia for vaginal delivery. Anesth Analg 1978; 57(1): 121-3.

[http://dx.doi.org/10.1213/00000539-197801000-00026] [PMID: 243 71]

[23] Mistry RB, Nahata MC. Ketamine for conscious sedation in pediatric emergency care. Pharmacotherapy 2005; 25(8): 1104-11.

[http://dx.doi.org/10.1592/phco.2005.25.8.1104] [PMID: 16207101]

[24] Green SM, Krauss B. Clinical practice guideline for emergency department ketamine dissociative sedation in children. Ann Emerg Med 2004; 44(5): 460-71.

[http://dx.doi.org/10.1016/j.annemergmed.2004.06.006] [PMID: 155 20705]

[25] Powers AR III, Gancsos MG, Finn ES, Morgan PT, Corlett PR. Ketamine-induced hallucinations. Psychopathology 2015; 48(6): 376-85.

[http://dx.doi.org/10.1159/000438675] [PMID: 26361209]

\section{(C) 2019 Salah et al.}

This is an open access article distributed under the terms of the Creative Commons Attribution 4.0 International Public License (CC-BY 4.0), a copy of which is available at: (https://creativecommons.org/licenses/by/4.0/legalcode). This license permits unrestricted use, distribution, and reproduction in any medium, provided the original author and source are credited. 